\title{
THE EFFECTS OF TRAINING ON DIFFERENT SURFACES, ON BALANCE AND GAIT PERFORMANCE IN STROKE HEMIPLEGIA
}

\author{
EFEITOS DO TREINAMENTO EM DIFERENTES SUPERFICIES DE APOIO SOBRE O EQUILIBRRIO EO \\ DESEMPENHO DA MARCHA EM HEMIPLEGIA POR ACIDENTE VASCULAR CEREBRAL
}
EFECTOS DEL ENTRENAMIENTO SOBRE EL EQUILIBRIO Y EL DESEMPEÑO DE LA MARCHA EN DIFERENTES
SUPERFICIES DE APOYO EN LA HEMIPLEJIA INDUCIDA POR ACCIDENTE CEREBROVASCULAR

\section{Hyun-Seung Rhyu' (iD (Physical Education Professional) Soung-Yob Rhi (D) \\ (Physical Education Professional)}

1. Jungwon University, Department of Sport Education, Goesan, Korea. 2. Catholic Kwandong University, Department of Sports \& Health Management, Gangneung-si, Korea.

\section{Correspondence}

Soung-Yob Rhi

Catholic Kwandong University, Departments of Sports \& Health Management. Gangneung-si, Republic of Korea. ZIP Code: 25601 fltmdduq@cku.ac.kr

\begin{abstract}
Although many studies have focused on balance exercises for elderly or stroke patients, no comprehensive studies have investigated the use of training on different surfaces (TDS) with analysis of gait performance in elderly male stroke patients. The active properties of balance and subjective reporting of functional gait ability were used to identify the effects of TDS. Static balance (SB), dynamic balance (DB) and gait analysis was measured in 30 elderly stroke patients. The patients were divided into the TDS group $(n=15)$ and a control group ( $C G, n=15)$. Fifteen elderly stroke patients underwent TDS five times a week for 12 weeks. The data was analyzed using repeated measures analysis of variance. Significant differences were observed between the two groups (TDS and Control): SB ( $p<0.0001$ ), DB (OSI: $p<0.0001$, APSI: $p<0.001$, MLSI: $p<0.004)$ and gait analysis (right: temporal step time: $p<0.0001$, temporal cycle time: $p<0.001$, temporal double support time: $p<0.0001$; left: temporal step time: $p<0.0001$, temporal cycle time: $p<0.0001$, temporal double support time: $p<0.0001)$. TDS in elderly male stroke patients suggests that the characteristics of gait performance in these patients may be improved by increasing static balance, dynamic balance and gait velocity. It is hoped that the results of this trial will provide new information on the effects of TDS on balance stability and gait ability in stroke patients, through changes in stability of the lower extremities. Level III, Case-control Study.
\end{abstract}

Keywords: Static Balance; Dynamic Balance; Gait analysis; Stroke; Hemiplegia.

\section{RESUMO}

Embora muitos estudos tenham se concentrado em exercícios de equilibrio para idosos e/ou pacientes com acidente vascular cerebral, nenhum estudo abrangente investigou o uso do treinamento em diferentes superfícies de apoio (TDS) para analisar o desempenho da marcha em pacientes idosos do sexo masculino com AVC. As propriedades ativas do equilíbrio e o relato subjetivo da capacidade funcional da march a foram usados para identificar os efeitos do TDS. O equilíbrio estático (SB), o equilíbrio dinâmico (DB) e a análise da marcha foram medidos em 30 pacientes idosos com AVC. Os pacientes foram divididos em grupo TDS (GTDS, $n=15$ ) e grupo controle (GC, $n=15$ ). Quinze pacientes idosos com AVC foram submetidos a TDS cinco vezes por semana durante 12 semanas. Os dados foram analisados por meio de análise de variância de medidas repetidas. Foram observadas diferenças significativas entre os dois grupos (GTDS e controle): $S B$ ( $p<0,0001$ ), DB (OSI: $p<0,0001$, APSI: $p<0,001$, MLSI: $p<0,004$ ) e análise da marcha (direita: tempo do passo: $p<0,0001$, tempo da passada (ciclo): $p<0,001$, tempo de duplo apoio: $p<0,0001$; esquerda: tempo do passo: $p<0,0001$, tempo da passada (ciclo): $p<0,0001$, tempo de duplo apoio: $p<0,0001$ ). OTDS em pacientes idosos do sexo masculino com AVC sugere que as características de desempenho da marcha podem ser melhoradas com o aumento do equilibrio estático, equilibrio dinâmico e da velocidade da marcha. Espera-se que os resultados deste estudo forneçam novas informações sobre os efeitos do TDS na estabilidade do equilíbrio e na habilidade de marcha em pacientes com AVC, por meio de mudanças na estabilidade dos membros inferiores. Nível de evidência III, Estudo de caso controle.

Descritores: Análise da marcha; Acidente vascular cerebral; Hemiplegia.

\section{RESUMEN}

Aunque muchos estudios se han centrado en los ejercicios de equilibrio para pacientes de edad avanzada y/o con accidentes cerebrovasculares, ningún estudio exhaustivo ha investigado el uso del entrenamiento en diferentes superficies de apoyo (TDS) para analizar el desempeño de la marcha en pacientes masculinos de edad avanzada con accidentes cerebrovasculares. Se utilizaron las propiedades activas del equilibrio y el informe subjetivo de la capacidad funcional de la marcha para identificar los efectos del TDS. Se midieron el equilibrio estático (SB), el equilibrio 
dinámico (DB) y el análisis de la marcha en 30 pacientes ancianos con ACV. Los pacientes fueron divididos en grupo TDS (GTDS, $n=15)$ y grupo de control $(C G, n=15)$. Quince pacientes de edad avanzada con ACV fueron sometidos a TDS cinco veces por semana durante 12 semanas. Los datos se analizaron mediante un análisis de desviación de medidas repetidas. Se observaron diferencias significativas entre los dos grupos (TDS y Control): $S B(p<0,0001$ ), $D B(O S): p<0,0001, A P S I: p<0,001$, MLSI: $p<0,004$ ) y análisis de la marcha (derecha: tiempo de paso temporal: $p$ $<0,0001$, tiempo de ciclo temporal: $p<0,001$, tiempo de doble apoyo temporal: $p<0,0001$; izquierda: tiempo de paso temporal: $p<0,0001$, tiempo de ciclo temporal: $p<0,0001$, tiempo de doble apoyo temporal: $p<0,0001$ ). El TDS en pacientes masculinos de edad avanzada con ACV sugiere que las características de desempeño de la marcha pueden mejorar con el aumento del equilibrio estático, el equilibrio dinámico y la velocidad de la marcha. Se espera que los resultados de este estudio proporcionen nueva información sobre los efectos del TDS en la estabilidad del equilibrio y en la capacidad de andar en pacientes con ACV a través de cambios en la estabilidad de las extremidades inferiores.

\section{Nivel de evidencia III, Estudio de caso-control.}

Descriptores: Análisis de la marcha; Accidente cerebrovascular; Hemiplejía.

\section{INTRODUCTION}

Medical technology for the prevention and treatment of stroke has been improving rapidly worldwide, and interest in stroke treatment is also growing. Stroke refers to tissue damage in the brain because of loss of blood supply, caused either by direct rupture of blood vessels or obstruction of blood vessels by a thrombus. ${ }^{1}$ Brain injury due to stroke has a direct effect on activities of daily living (ADL), paralysis and language impairment, visual impairment, gait impairment, and loss of balance and motor control. ${ }^{2,3}$ Thus, rehabilitation exercises for stroke patients focuses on training to restore ADL.

Hemiplegia due to stroke causes an imbalance between the left and right sides of the body, with restriction of movement due to reduced ability in gait, standing and sitting, and change of direction. Maintaining the center of mass is important to obtain stable movement of the body, which, in turn, requires proprioception, a sense of balance, constant body weight, and visual cognitive ability. ${ }^{4}$ When certain parts of the brain are injured, hemiparesis causes muscle weakness and motor impairment in the contralateral limbs, ${ }^{5}$ and $61-80 \%$ of the body weight is shifted to the healthy side. ${ }^{6}$ This results in restriction of gait-related movements.

In gait rehabilitation exercise, early intervention is important. Although post-stroke neurological and functional recovery are affected by the pathogenesis and location of the lesion, $90 \%$ recovery can be achieved within 3 months of onset, except in hemorrhagic stroke. ${ }^{7,8} \mathrm{Mo-}$ reover, the reduction of balance control ability and muscles recruitment increases the incidence of falls. ${ }^{9}$ Reduced coordination ability lend to loss of lower limb function in patients with post-stroke hemiplegia, and reduced physical activity restricts independent $A D L .{ }^{10}$

Along with recovering $A D L$, rehabilitation exercise is also important for restoring gait ability. Gait refers to moving the body from one place to another through alternating movements of the legs through a swing phase and a stance phase. The most basic gait pattern consists of continual movements in which the segments of the upper and lower limbs all interact. ${ }^{11}$ Gait is perceived as a complex movement by stroke patients, and thus is a cause of restricted mobility. In particular, balance ability during gait is divided into the ability to maintain the center of mass within a surface while minimizing sway of the upper and lower body during gait, and the ability to maintain the center of mass over the base of support while moving. ${ }^{12,13}$ Static balance in a standing position before gait, and dynamic balance during gait are both important factors.

During gait, the center of mass should always be over the base of support. In gait rehabilitation, experience on various surfaces is required for a stable gait. The ground can be divided into stable and unstable surfaces; rehabilitation exercise using stable surfaces can help improve static balance and gait ability ${ }^{14}$ while unstable surfaces stimulate joint proprioceptors in the upper and lower limbs, affecting dynamic balance and the ability to control the center of mass during gait. 15,16

Rehabilitation exercises to restore balance and improve function include balance training, lower limb muscle strengthening, visual feedback training and physical stabilization exercise using proprioceptive neuromuscular facilitation. ${ }^{17,18}$ Moreover, there has been active research on different methods to restore balance and gait ability in stroke patients, but the methods presented are simplistic, and gait related research is lacking. In particular, research rehabilitation exercises using movements required for stroke patients and post-stroke rehabilitation exercises are limited, owing to difficulties in the research process due to patient characteristics.

In this study, we aimed to use a various surfaces exercise (VSE) for 12 weeks in stroke patients, and to analyze changes in static and dynamic balance and gait ability, thus providing data for precise and appropriate rehabilitation exercises.

\section{PATIENTS AND METHODS}

The subjects were 30 male stroke patients from Bucheon (SM Sports Rehabilitation Center, South Korea) who wished to participate in the study. They were classified into the 2 groups: VSEG (various surfaces exercise group; $n=15)$ or the control group (CG; $n=15)$. The participants were patients diagnosed with post-stroke hemiplegia within the last 3 months, and could understand instructions and show an appropriate response (cognitive function scale $\geq 23$, able to walk independently). The physical characteristics of the subjects are shown in the Table 1.

Table 1. Subject characteristics.

\begin{tabular}{|c|c|c|c|}
\hline $\begin{array}{l}\text { Characteristics } \\
\text { (Male, } \mathrm{N}=30 \text { ) }\end{array}$ & VSEG $(n=15)$ & CG $(n=15)$ & Paralysis \\
\hline Age (years) & $66.73 \pm 1.86$ & $66.53 \pm 1.50$ & \multirow{3}{*}{ Rt. hemiplegia } \\
\hline Weight(kg) & $64.13 \pm 6.61$ & $70.53 \pm 7.85$ & \\
\hline Height(cm) & $167.0 \pm 4.44$ & $169.4 \pm 4.44$ & \\
\hline
\end{tabular}

\section{METHODS}

\section{Various surfaces exercise program}

The VSE used in this study is a modified and supplemented version of the exercise program used in studies by Rose, ${ }^{19}$ Schinkel-Ivy, et al. ${ }^{20}$ and Kong et al. ${ }^{14}$ First, as a warm-up, the patients performed 10 minutes of static stretching; for the main exercise, the patients performed a program to improve balance and gait ability using stable and unstable 
surfaces (Figure 1). The VSE was performed for 70 mins, 5 times per week, for 12 weeks, and the control group did not participate in any specific VSE program (Table 2). All subjects were informed of the experimental purpose and procedures and signed a consent form.

\section{Static balance measurement}

Static balance was measured using the one-leg balance. The subject were shown the test which the patient stands on the ground on one leg, lifts the other leg with the knee at $90^{\circ}$ flexion, places both hands on their hips, and open their eyes, and the time until the patient moves is measured in seconds. The left and the right leg were measured separating the one-leg test. The maximum value of two trials was recorded. ${ }^{21}$

\section{Dynamic balance measurement}

Dynamic balance ability was measured using balance system SD (BIODEX Medical System, USA). Dynamic balance was measured by a postural stability balance test, using an adjustable circular plate, a monitor for visual balance control, a computer to measure the patient's movement and analyze the data, and a printer for data output. Dynamic balance of the overall stability was measured in all body movement, and anterior/posterior stability was measured in anterior and posterior movement, and medial/lateral stability was measured in medial and lateral movement. The best value of two trials was recorded.

\section{Gait ability measurement}

The gait analysis equipment (GaitRite gait analyzer, CIR system, Inc, USA) was calibrated before measurement, and the subjects practiced to prevent errors. Before each measurement, the patient's leg length (distance from the greater trochanter to the inferior margin of the lateral malleolus), height, and weight were measured, and the characteristics were entered into the computer. The variables measured to test differences in gait between the left and right legs were as follows: the

Table 2. VSE program.

\begin{tabular}{c|c|c}
\hline \multicolumn{3}{|c}{ Protocol } \\
\hline Position & Type & Time \\
\hline \multirow{2}{*}{ Standing } & Stretching & 10 \\
\hline \multirow{2}{*}{ Walking } & Stable surface training & 15 \\
\cline { 2 - 3 } & Unstable surface training & 15 \\
\hline & Stable surface training & 15 \\
\cline { 2 - 3 } & Unstable surface training & 15 \\
\hline
\end{tabular}

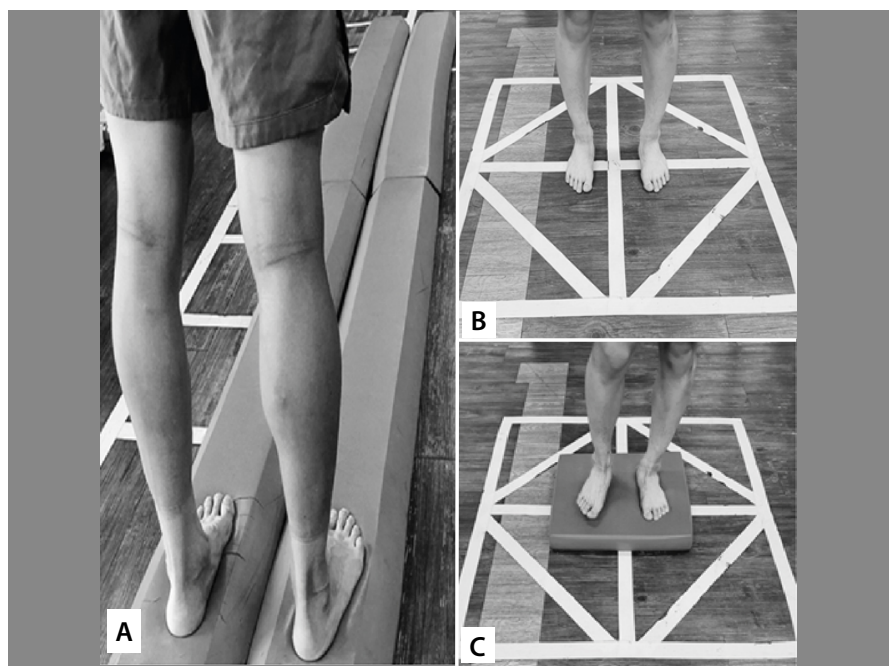

Figure 1.VSE program position (A: unstable surface walking, B: stable surface standing, C: unstable surface standing). temporal parameters were step time and cycle time, which reflect the time from contact of one foot to contact of the other foot, and double support time, which measures the time during which both feet are in contact with the floor simultaneously; the spatial parameters were step length and stride length, calculated by measuring the distance, in the horizontal axis of the GaitRite mat, from the heel of the trailing foot to the heel of the leading foot.

\section{Statistical analysis}

All data were expressed as means with standard deviations using SPSS ver. 22.0 for Windows (SPSS, Inc., Chicago, IL, USA). The one sample Kolmogorov-Smirnov test was conducted to examine normality. The equal variance test was conducted using Levene's equal variance $F$ test. Static balance, dynamic balance, and gait analysis were measured in the 30 subjects, and repeated-measures analysis of variance was used to examine the relationships between the groups and the measured variables. Statistical significance was accepted for $p$-values $<0.05$.

\section{RESULTS}

\section{Static balance measurement}

Table 3 shows the changes in static balance ability. When the static balance was measured in stroke patients using the one leg standing balance test (OLST), comparing post-exercise with pre-exercise, the various surfaces exercise group (VSEG) and the control group (CG) showed a significant difference depending on the time point $(F=50.986)$.

\section{Dynamic balance measurement}

Table 4 shows the results of dynamic balance measurement. The VSEG and CG showed significant differences depending on the time point for overall stability index (OSI, F=5.693), anterior posterior stability index(APSI, F=12.696), and medial lateral stability index(MLSI, F=10.020).

\section{Gait analysis}

Table 5 shows the results of the gait analysis. For the right side, the VSEG and CG showed significant differences depending on the time points for temporal step time( $F=24.467)$, temporal cycle time( $F=41.215)$, and temporal double support time $(F=17.435)$. Significant differences in group-by-time interactions for the left side on the time points for temporal step time $(F=48.537)$, temporal cycle time $(F=29.240)$, and temporal double support time $(F=28.974)$.

Table 3. Results of the static balance (Unit: sec).

\begin{tabular}{|c|c|c|c|c|c|c|}
\hline \multirow{2}{*}{\multicolumn{2}{|c|}{ Trial }} & \multirow{3}{*}{$\begin{array}{c}\text { Group } \\
\text { VSEG }\end{array}$} & \multirow{3}{*}{$\begin{array}{l}\text { Pre Test } \\
5.16 \pm 2.99\end{array}$} & \multirow{3}{*}{$\begin{array}{c}\text { Post Test } \\
17.39 \pm 4.96 \\
\end{array}$} & \multicolumn{2}{|c|}{ Interaction (Group X Time) } \\
\hline & & & & & $F$ & $n$ \\
\hline \multirow{2}{*}{ SB } & \multirow{2}{*}{ OLSBT } & & & & \multirow{2}{*}{50.986} & \multirow{2}{*}{$.000^{* * *}$} \\
\hline & & $C G$ & $5.73 \pm 2.65$ & $8.0 \pm 3.5$ & & \\
\hline
\end{tabular}

Values are Mean \pm SD, SB: static balance, OLSBT: one leg standing balance test, VESG: various surfaces exercise group CG: control group. " $p<0.05 ; " * p<0.01,{ }^{* * *} p<0.001$. The significance levels were evaluated using the repeated ANOVA.

Table 4. Results of the dynamic balance (Unit: sec).

\begin{tabular}{|c|c|c|c|c|c|c|}
\hline \multirow{2}{*}{\multicolumn{2}{|c|}{ Trial }} & \multirow{3}{*}{$\begin{array}{l}\text { Group } \\
\text { VSEG }\end{array}$} & \multirow{3}{*}{$\begin{array}{l}\text { Pre Test } \\
2.32 \pm 0.71 \\
\end{array}$} & \multirow{3}{*}{$\begin{array}{l}\text { Post Test } \\
1.24 \pm 0.50\end{array}$} & \multicolumn{2}{|c|}{ Interaction (Group X Time) } \\
\hline & & & & & $F$ & $p$ \\
\hline \multirow{6}{*}{$\mathrm{DB}$} & \multirow{2}{*}{ OSI } & & & & \multirow{2}{*}{5.693} & \multirow{2}{*}{$.000^{* * *}$} \\
\hline & & $C G$ & $4.30 \pm 1.36$ & $4.41 \pm 1.47$ & & \\
\hline & \multirow{2}{*}{ APSI } & VSEG & $1.65 \pm 0.28$ & $0.84 \pm 0.37$ & \multirow{2}{*}{12.696} & \multirow{2}{*}{$.001^{* *}$} \\
\hline & & $C G$ & $2.32 \pm 1.04$ & $2.91 \pm 1.02$ & & \\
\hline & \multirow{2}{*}{ MLSI } & VSEG & $4.60 \pm 2.57$ & $0.66 \pm 0.19$ & \multirow{2}{*}{10.020} & \multirow{2}{*}{$.004^{* *}$} \\
\hline & & $C G$ & $2.18 \pm 0.88$ & $4.47 \pm 7.15$ & & \\
\hline
\end{tabular}

Values are Mean \pm SD, OSI: overall stability index, APSI: anterior posterior stability index, MLSI: medial lateral stability index. VSEG: various surfaces exercise group, CG: control group, " $p<0.05$; " $p<0.01$, " $p<0.001$. The significance levels were evaluated using the repeated ANOVA. 
Table 5. Results of the gait analysis (Unit: sec)

\begin{tabular}{|c|c|c|c|c|c|c|}
\hline \multirow{2}{*}{\multicolumn{2}{|c|}{ Trial }} & \multirow{3}{*}{$\begin{array}{l}\text { Group } \\
\text { VSEG } \\
\end{array}$} & \multirow{3}{*}{$\begin{array}{l}\text { Pre Test } \\
1.23 \pm 0.12\end{array}$} & \multirow{3}{*}{$\begin{array}{l}\text { Post Test } \\
1.13 \pm 0.10\end{array}$} & \multicolumn{2}{|c|}{ Interaction (Group X Time) } \\
\hline & & & & & $F$ & $n$ \\
\hline \multirow{6}{*}{ Right } & \multirow{2}{*}{ TST } & & & & \multirow{2}{*}{24.467} & \multirow{2}{*}{$.000^{* * *}$} \\
\hline & & $C G$ & $1.23 \pm 0.14$ & $1.20 \pm 0.14$ & & \\
\hline & \multirow{2}{*}{$\mathrm{TCT}$} & VSEG & $2.24 \pm 0.11$ & $2.06 \pm 0.36$ & \multirow{2}{*}{41.215} & \multirow{2}{*}{$.000^{* * * *}$} \\
\hline & & $C G$ & $2.22 \pm 0.14$ & $2.21 \pm 0.12$ & & \\
\hline & \multirow{2}{*}{ TDST } & VSEG & $0.62 \pm 0.11$ & $0.52 \pm 0.14$ & \multirow{2}{*}{17.435} & \multirow{2}{*}{$.000^{* * *}$} \\
\hline & & $C G$ & $0.62 \pm 0.89$ & $0.61 \pm 0.09$ & & \\
\hline \multirow{6}{*}{ Left } & \multirow{2}{*}{ TST } & VSEG & $1.17 \pm 0.10$ & $1.00 \pm 0.09$ & \multirow{2}{*}{48.537} & \multirow{2}{*}{$.000^{* * *}$} \\
\hline & & $C G$ & $1.17 \pm 0.11$ & $1.17 \pm 0.11$ & & \\
\hline & \multirow{2}{*}{$\mathrm{TCT}$} & VSEG & $2.13 \pm 0.06$ & $2.05 \pm 0.03$ & \multirow{2}{*}{29.240} & \multirow{2}{*}{$.000^{* * * *}$} \\
\hline & & $C G$ & $2.17 \pm 0.10$ & $2.16 \pm 0.08$ & & \\
\hline & \multirow{2}{*}{ TDST } & VSEG & $0.54 \pm 0.14$ & $0.46 \pm 0.15$ & \multirow{2}{*}{28.974} & \multirow{2}{*}{$.000^{* * *}$} \\
\hline & & CG & $0.51 \pm 0.11$ & $0.51 \pm 0.10$ & & \\
\hline
\end{tabular}

Values are Mean \pm SD, TST: temporal step time, TCT: temporal cycle time, TDST: temporal double support time VESG: various surfaces exercise group, CG: control group, " $p<0.05$; " $p<0.01, " ' p<0.001$. The significance levels were evaluated using the repeated ANOVA.

\section{DISCUSSION}

The symptoms of stroke include reduced motor ability due to muscle weakening, stiffness, pain, and deficits of balance and the sensory organs. ${ }^{22}$ Due to impaired balance, stroke patients show around twice as much postural sway in a standing position compared to healthy individuals and show reduced stability and balance for postural maintenance. ${ }^{23-25}$ For these reasons, when stroke patients maintained an upright posture, anteroposterior and left-right asymmetry and altered physical structure led to ankle dysfunction and instability, and these problems caused ADL impairments. ${ }^{26}$

In this study, after using the VSE, we observed an increase in static balance ability. These results are consistent with Jain \& Shah. ${ }^{27}$ who suggested that static balance is controlled by the vestibular, visual and somatosensory systems. Liu et al. ${ }^{28}$ and Runge et al. ${ }^{29}$ reported that various surfaces exercise should be emphasized and that stable balance exercise should be avoided to increase gait, balance and decrease risk of injury falls in stroke patients. Van Duijnhoven et al. ${ }^{30}$ studied stroke patients (systematic review and meta-analysis) and reported that using a balance and/or weight shifting training, gait training and multisensory training program for stroke patients using a various balance training method and reported improvements in muscle strength, balance and muscle endurance in balance test. These results are consistent with our results and support the positive effects of VSE. In this regard, static balance control was improved by rehabilitation exercise, and this is thought to be because bodyweight exercise using the forefoot and rearfoot on a various surfaces maintained the position of the body's center of mass and the center of pressure of the supporting foot. In addition, various surfaces exercise improved static balance ability through somatic signals conveyed to the central nervous system by proprioceptors, resulting in motor-sensory processing by subconscious, rather than conscious responses in the muscles, joints, ligaments and tendons of the lower limb. 29,31 Thus, appropriate stimulation of the paralyzed parts of the body is important to ensure physical balance and balance ability, and continual VSE can the positive effects.

Dynamic balance ability is an important factor in gait, 32,33 positional sense and physical balance, and a decrease in aspects of dynamic balance exposes the patient to the risk of injury even if only due to impaired movement and physical balance. ${ }^{34}$ In this study, significant differences in OSI, APSI, MLSI were observed after VSE. Thus, VSE group showed a decrease in APSI, indicating improved anterior and posterior stability. In a study of control group (25 patients) and experimental group (25 patients) stroke patients, Liu et al. ${ }^{28}$ reported that 4 weeks of sit-to-stand training increased anterior/posterior and medial/lateral balance and improved bodyweight mobility in experimental training for stroke patients. Consistent with previous studies, ${ }^{28,32,33,34}$ we also observed positive effects on APSI using a VSE, by stabilizing movement of the body's center of mass through various exercises to improve bodyweight movement and positional sense of the foot, such as changing the base of support and standing on the forefoot and rearfoot. MLSI requires bodyweight load, left-right balance, ${ }^{35}$ and changes of direction in the horizontal plane, and impairment in this aspect of balance exposes the patient to risk of injury even if only due to physical asymmetry and decline in function. ${ }^{20}$ In this study, MLSI decreased afterVSE, indicating an increase in medial/lateral stability. Hsiao et al. ${ }^{36}$ used lateral bodyweight exercise in stroke patients and reported a correlation between gait speed and balance; in this study, VES is thought to have helped improve MLSI and influenced the stability of hip extension during gait effects on the hip adductors and abductors. Moreover, the results for APSI and MLSI are thought to have affected the measurement of OSI. OSI measures changes in position in all directions. Ahmed et al. ${ }^{37}$ investigated anterior/posterior and medial/lateral balance training using a Biodex Balance System in 45-65 years old stroke patients, and observed an increase in OSI, demonstrating improved dynamic balance, as well as an increase in lower limb muscle strength and ankle range of motion, resulting in improved static and dynamic balance. In this study, VES improved lower limb coordination and muscle balance interactions; this resulted in an increase in conduction speed of over $15-30 \mathrm{~m} / \mathrm{s}$, improving muscle and neural stimulation, ${ }^{38}$ and increasing gait velocity, step count, and double support time, reducing step length, and affecting physical stability during gait. ${ }^{39}$ Various surfaces exercise affects OSI improvements in the overall sense of direction, function of paralyzed body parts, coordination and muscle strength of the lower limbs, left-right bodyweight loading, and changes in the body's center of mass. Thus, dynamic balance ability after using VSE improves gait ability and physical balance, and implementation of a continuous, long-term program has a positive effect on dynamic balance.

Gait is important for the recovery of ADL in hemiplegic stroke patients, and this is because movements in of independent living, such as going to the lavatory, walking and climbing are especially related to gait ability. The loss of active muscle contraction, muscle weakening, physical asymmetry and ankle instability in hemiplegic patients restrict $\mathrm{ADL}$ and increase the risk of injury. ${ }^{40}$ Snaterse et al. ${ }^{41}$ and Belda-Lois et al. ${ }^{42}$ reported that paralysis occur due to the central nervous system damage, resulting in a gait pattern showing circular movement of one leg, and that reduced gait ability is closely related to the cycle time, consisting of the stance phase and the swing phase, as well as the support time and the step time. In this study, when gait ability was measured after VSE, we observed significant increases in step time, cycle time, and support time. Thus, through VSE, static balance ability affects physical stability during one-leg support in the swing phase, and support time decreases; dynamic balance ability affects coordination of the upper and lower body during the stance and swing phase, leading to improved hip joint function, improved ability to shift the body weight, and increased limb stability, which results in longer stride length and affects step time. In particular, the shorter step time for the right foot, which was the paralyzed side, indicated that the right foot spent less time with toe-off. Fukuchi et al. ${ }^{43}$ examined leg movements during gait from a functional perspective and found that, the main role of hip extension is to securely fix the relationship between one leg and the trunk when lifting the other leg from the ground. Therefore, shorter step time stabilizes fixation of the opposite leg, provides a strong stimulus to improve function of the opposite leg, and decreases cycle time and double support time, ultimately improving the quality of gait. Mochizuki et al. ${ }^{44}$ observed changes in gait velocity and step length depending on balance, and 
reported that this was related to improvements in gait ability and fall risk. In particular, in stroke patients, various surfaces exercise affects limb coordination and gait ability by improving static and dynamic balance, and this ultimately increases physical stability and improves the quality of gait. As a result, the VES in this study needs to be actively used in elderly hemiplegic stroke patients, and we believe that this will enable improvements in physical balance, gait ability, and quality of life.

\section{CONCLUSION}

In conclusion, we found increased static and dynamic balances after VSE, and gait factors (temporal step time, temporal cycle time, temporal double support time) improved after VSE compared with those in the CG. Thus, gait and balance VSE increased balance and gait function in stroke hemiplegia patients. VSE should be applied continuously during rehabilitation training.

\section{ACKNOWLEDGEMENTS}

We would like to thank all the participants and research staff who assisted with the data collection for the project.

All authors declare no potential conflict of interest related to this article

AUTHORS' CONTRIBUTIONS: Each author made significant individual contributions to this manuscript. Hyun-Seung Rhyu: This author made a significant contribution to the overall outline and subject selection of this manuscript. Soung-Yob Rhi: This author has made significant contributions to experiments and manuscripts in this manuscript.

\section{REFERENCES}

1. Gomes J, Wachsman AM. Handbook of clinical nutrition and stroke. In: Corrigan, Mandy L, Escuro, Arlene A, Kirby, Donald F. Chapter 2: Nutrition and Health. New York: 2013.

2. Chae SH, Kim YL, Lee SM. Effects of phase proprioceptive training on balance in patients with chronic stroke. J Phys Ther Sci 2017; 29: 839-844.

3. McGlinchey MP, James J, McKevitt C, Douiri A, McLachlan S, Sackley CM. The effect of rehabilitation interventions on physical function and immobility-related complications in severe stroke-protocol for a systematic review. Syst Rev 2018;7(1):197.

4. Zijlstra A, Mancini M, Chiari L. Biofeedback for training balance and mobility tasks in older populations: a systematic review. J Neuroeng Rehabil 2010;7:58

5. Bohannon RW. Muscle strength and muscle training after stroke. J Rehabil Med 2007;39(1):14-20

6. Sackley CM, Baguly BI. Visual feedback after stroke with balance performance monitor: two single case studies. Clinical Rehabilitation 1993;7(3):189-195.

7. Anderson TP. Rehabilitation of patient with complete stroke 4th Ed. Krusen's Handbook of Physical Medicine and Rehabilitation 1990.

8. Karakaya MG, Rutbi H, Akpinar E, Yildirim A, Karakaya IÇ. Effect of ankle proprioceptive training on static body balance. J Phys Ther Sci 2015;27:3299-3302.

9. Nyberg L, Gustafson Y. Patient falls in stroke rehabilitation: A challenge to rehabilitation strategies. Stroke 1995;26(5):838-842.

10. Chandler JM, Duncan PW, Studenski SA. Balance performance on the postural stress test: comparison of young adults, healthy elderly, and fallers. Phys Ther 1990;70(7):410-415

11. Alice Bonnefoy M, Armand S. Normal gait: chapter 16. Nova Science Publishers 2015; 200-213.

12. Pinedo S, Erazo P, Tejada P, Lizarraga N, Aycart J, Miranda M, Zaldibar B, Gamio A, Gomez I, Sanmartin $\checkmark$, Bilbao A. Rehabilitation efficiency and destination on discharge after stroke. Eur J Phys Rehabil Med 2014;50(3):323-333

13. Januario F, Campos I, Amaral C. Rehabilitation of postural stability in ataxic/ hemiplegic patients after stroke. Disabil Rehabil 2010;32(21):1775-1779.

14. Shumway-Cook A, Anson D, Haller S. Postural sway biofeedback: its effect on reestablishing stance stability in hemiplegic patients. Arch Phys Med Rehabil 1988;69(6):395-400.

15. Kong HN, Bang DH, Shin WS. Effects of balance training on different support surface on balance and Gait in patients with chronic stroke. Journal of The Korean Society of Physical Medicine 2015;10(3):57-65.

16. Cumming Robert $\mathrm{G}$, Klineburg J. Fall frequency and characteristics and the risk of hip fractures. Journal of the American Geriatrics Society 1994;42(7):774-778.

17. Zhang WW, Speare S, Churilov L, Thuy M, Donnan G, Bernhardt J. Stroke rehabilitation in china: a systematic review and meta-analysis. Int I Stroke 2014;9(4):494-502.

18. Lee SY, Park JS, Lee DH. Effects of an exercise program using aero-step equipment on the balance ability of normal adults. J Phys Ther Sci 2013;25(8):937-940.

19. Richardson JK, Sandman D, Vela S. A focused exercise regimen improves clinical measures of balance in patients with peripheral neuropathy. Arch Phys Med Rehabil 2001;82(2):205-209.

20. Rose DJ. Fall proof! a comprehensive balance and mobility training program. 2nd Edition: Human Kinetics, 2010.

21. Schinkel-Ivy A, Inness EL, Mansfield A. Relationships between fear of falling, balance confidence, and control of balance, gait, and reactive stepping in individuals with sub-acute stroke. Gait Posture 2016;43:154-159.

22. Rodrigo Antonio G, Rony S, Francisco Aniceto R, David Andrés A, Pablo Andrés O. Relationship between unipedal stance test score and center of pressure velocity in elderly. Rev Esp Geriatr Gerontol 2011;46(5):256-260

23. Ghomashchi H. Investigating the effects of visual biofeedback therapy on recovery of postural balance in stroke patients using a complexity measure. Top Stroke Rehabil 2016;23(3):178-183.
24. Badke MB, Sherman J, Boyne P, Page S, Dunning K. Tongue-based biofeedback for balance in stroke: results of an 8-week pilot study. Clinical Trial 2011;92(9):1364-1370.

25. Middleton A, Merlo-Rains A, Peters DM, Greene JV, Blanck EL, Moran R, Fritz SL. Body weight-supported treadmill training is no better than overground training for individuals with chronic stroke: a randomized controlled trial. Randomized Controlled Trial 2014;21(6):462-476.

26. MacKay-Lyons M, Billinger SA, Eng JJ, Dromerick A, Giacomantonio N, Hafer-Macko C, Macko R, Nguyen E, Prior P, Suskin N, Tang A, Thornton M, Unsworth K. Aerobic Exercise Recommendations to Optimize Best Practices in Care After Stroke: AEROBICS 2019 Update. Phys Ther 2020;100(1):149-156

27. Jain A, Shah C. Effectiveness of three different surfaces for balance training on ambulant stroke Patients - a comparative study. International Journal of Science and Research 2015;6:2319-7064.

28. Liu M, Chen J, Fan W, Mu J, Zhang J, Wang L, Zhuang J, Ni C. Effects of modified sit-to-stand training on balance control in hemiplegic stroke patients: a randomized controlled trial. Clin Rehabil 2016;30(7):627-636

29. Lee JY, Park JS, Lee DH, Roh HY. The Effects of Exercising on Unstable Surfaces on the Balance Ability of Stroke Patients. J Phys Ther Sci 2011;23:789-792.

30. Van Duijnhoven HJ, Heeren A, Peters MA, Veerbeek JM, Kwakkel G, Geurts AC, Weerdesteyn V. Effects of Exercise Therapy on Balance Capacity in Chronic Stroke: Systematic Review and Meta-Analysis. Stroke 2016;47(10):2603-2610.

31. Tsaklis PV, Grooten WJ, Franzén E. Effects of weight-shift training on balance control and weight distribution in chronic stroke: a pilot study. Top Stroke Rehail 2012;19(1):23-31.

32. Vistamehr A, Balasubramanian CK, Clark DJ, Neptune RR, Fox EJ. Dynamic balance during walking adaptability tasks in individuals post-stroke. J Biomech 2018;6(74):106-115.

33. Bower K, Thilarajah S, Pua YH, Williams G, Tan D, Mentiplay B, Denehy L, Clark R. Dynamic balance and instrumented gait variables are independent predictors of falls following stroke. J Neuroeng Rehabil 2019;16(1):3.

34. Yom C, Cho HY, Lee B. Effects of virtual reality-based ankle exercise on the dynamic balance, muscle tone and gait of stroke patients. J Phys Ther Sci 2015;27(3):845-849.

35. Seo KC, Kim HA. The effects of ramp gait exercise with PNF on stroke patients' dynamic balance. J Phys Ther Sci 2015;27(6):1747-9.

36. Hsiao H, Gray VL, Creath RA, Binder-Macleod, SA, Rogers MW. Control of lateral weight transfer is associated with walking speed in individuals post-stroke. Journal of Biomechanics 2017;60:72-78

37. Ahmed GM, Nassif AA, Nassag BE, Fahmy EM, Hanna SN. Relationship between the Balance Evaluation System Test and The Biodex Stability System as a Measurement of Balance in Stroke Patients. Med. J. Cairo Univ 2016;84(2):375-381.

38. Nordin M, Frankel VH. Biomechanics of the musculoskeletal system 4nd ed. Philadelphia London: Lea and Febiger, 2012.

39. Silva MRE, Jacinto J. Velocity Determinants in Spastic Patients after Stroke-A Gait Analysis Study. Neurol Int 2020;12(3):48-54.

40. Beyaert C, Vasa R, Frykberg GE. Gait post-stroke: Pathophysiology and rehabilitation strategies. Neurophysio Clin 2015;45(4-5):335-355.

41. Snaterse M, Ton R, Kuo AD, Donelan JM. Distinct fast and slow processes contribute to the selection of preferred step frequency during human walking. J Appl Physiol 2011;110(6):1682-90.

42. Belda-Lois JM, Mena-del Horno S, Bermejo-Bosch I, Moreno JC, Pons JL, Farina D, et al. Rehabilitation of gait after stroke: a review towards a top-down approach. J Neuroeng Rehabil 2011;8:66.

43. Fukuchi CA, Fukuchi RK, Duarte M. Effects of walking speed on gait biomechanics in healthy participants: a systematic review and meta-analysis. Syst Rev 2019;8(1):153.

44. Mochizuki L, Bigongiari A, Franciulli PM, Francica JV, Alonso AC, Ervilha UF, et al. The effect of gait training and exercise programs on gait and balance in post-stroke patients. Medical Express 2015;2(4) 